\title{
Austria in the COVID-19 pandemic - Citizens' satisfaction with crisis measures and communication
}

Institute for Public Management $\&$ Governance, at the Vienna University of Economics and Business (WU)

April 2020

Authors: Jurgen Willems, Monika Knassmüller, Falk Ebinger, Katharina Dinhof, Moritz Schmid

Administrative support: Lisa Sauberer

Institute for Public Management \& Governance (Website - Twitter - Fides)

WU Vienna University of Economics and Business

Welthandelsplatz 1, Building D2, Entrance B (level 1)

A-1020 Vienna, Austria

Email: pubmgt@wu.ac.at

Phone: +43/1/31336 - 4232

For a German-language version of this study, we refer to: https://doi.org/10.31219/osf.io/g8qhf 


\section{Summary}

Funding: This project is funded by the Vienna Science and Technology Fund (Wiener Wissenschafts-, Forschungs- und Technologiefonds - WWTF) (Website - Twitter), through project COV20-039, and by the Institute for Public Management \& Governance, at the Vienna University of Economics and Business (WU) (Website - Twitter - Fides).

Background: We assess satisfaction about various aspects of the 2020 COVID-19 crisis for a representative sample of 1798 respondents living in Austria. Survey questions focused on respondents' satisfaction about how the federal government, media, other citizens, their neighbors, employers, colleagues, and respondents themselves deal with the COVID-19 crisis. The goal of this study is to give a descriptive overview of these aspects of satisfaction, and quantitatively explore whether substantial differences exist for particular subgroups.

Data \& methods: Respondents were sampled based on representativeness criteria for region (Bundesland), age, and gender. Additional background variables were asked regarding education, occupation, and sector of employment for those respondents being employed $(\mathrm{n}=876)$. Eight satisfaction items were relevant for the total sample of respondents; Another six items were only relevant and presented to those respondents that indicated to be employed. These additional items focus on how satisfied respondents were with how their employer and colleagues deal with the COVID-19 crisis, and how they comply themselves with the COVID-19 measures of their employer.

All satisfaction items started with "How satisfied are you with, ..." and respondents could answer on a 7-point Likert scale, with numbered answer options ranging from very unsatisfied $(-3)$ to very satisfied $(+3)$, with 0 as the middle option. The full list of satisfaction items is given at the end of this study. The survey was administered in German. Items were presented in random order for each respondent, and an additional item was included as an attention question. Respondents failing to answer this attention question correctly were removed for further analysis and reporting, based on the assumption that they were fast-clicking through the survey and did not contemplate their answers.

We used a Qualtrics survey, and respondents were addressed by use of a professional panel provider (Qualtrics Panels). Data were collected from 17 April until 29 April (2020). Despite the aimed representativeness with respect to region (Bundesland), age, and gender for this sample, it has to be noted that at this point no further measures have been taken to weight the dataset for other variables. Descriptive statistics are reported at the end of this document. The raw data and full survey questions are available at https://osf.io/g8hn9/

Results: For the graphs in this study, satisfaction items are ranked based on the sample mean, from most satisfied (at the top of the graph) to least satisfied (at the bottom of the graph). Mean values are indicated with a dot, along with the $95 \%$-confidence interval around the mean. For the overall reporting of mean values for the total sample and the subsample of employed respondents, item mean scores are also given above the confidence intervals. For other figures in this study, graphs report differences for subgroups based on the demographic variables.

Main findings and conclusion: Overall, people living in Austria are satisfied with the various crisis management elements of the COVID-19 pandemic, as answers are mainly at the positive side of the response scale that ranges from -3 (Very unsatisfied) to +3 (Very satisfied). Citizens are most satisfied with how well they themselves comply with the measures of the federal government (and/or their employer) to overcome the Corona crisis, and about how they are able to comply with these measures. In contrast, they are least satisfied with how other citizens and neighbors comply with the measures, and on how national media report on the measures. Splitting-up satisfaction evaluations for gender, age, region, level of education, occupation, or sector of employment does show some small but no substantial differences for particular subgroups. 


\section{Citizens $(\mathrm{n}=1798)$}

\subsection{General}

... how well you are complying yourself with the government's measures
to cope with the Corona crisis?
... how you are able to comply with the measures taken by the
government to cope with the Corona crisis?

Overall, mean values for the satisfaction items are clearly at the positive side of this scale. Respondents are most satisfied about how they themselves are able to comply with the measures taken by the federal government and how well they are implementing the government's measures to deal with the COVID-19 crisis. Moreover, respondents are still satisfied, but to a lesser extent about how the government and others in Austria are dealing with the crisis. Respondents are least satisfied about the way the national media (newspapers, television, radio, etc.) report on the government's measures.

Download figure: https://doi.org/10.6084/m9.figshare.12217964 


\section{$2.2 \quad$ Age}

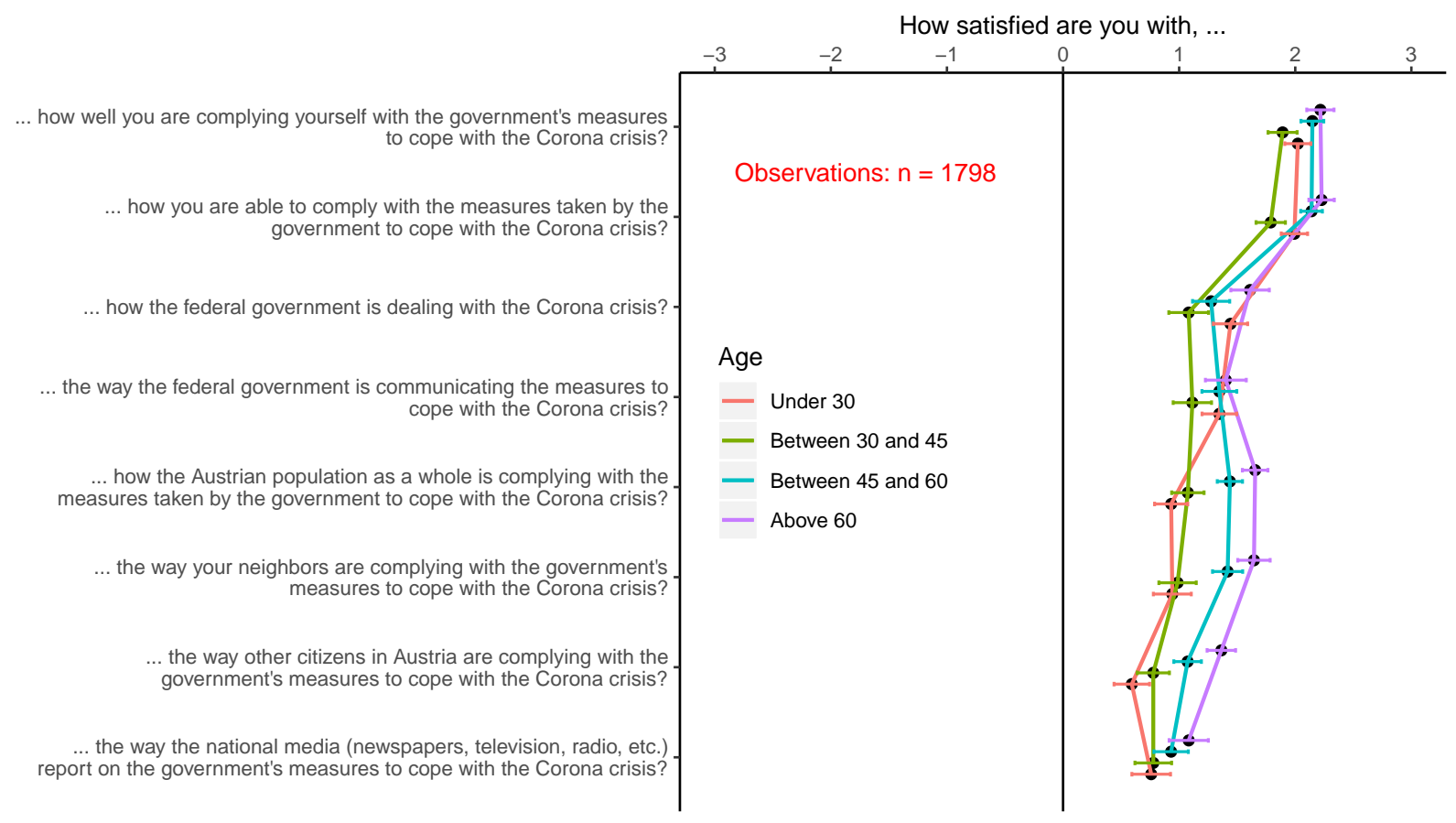

We can observe an age effect for satisfaction on how others deal with the government's COVID-19 measures. This means: the older people are, the more satisfied they are about how others comply with the COVID-19 measures.

Download figure: https://doi.org/10.6084/m9.figshare.12218006 


\subsection{Gender}

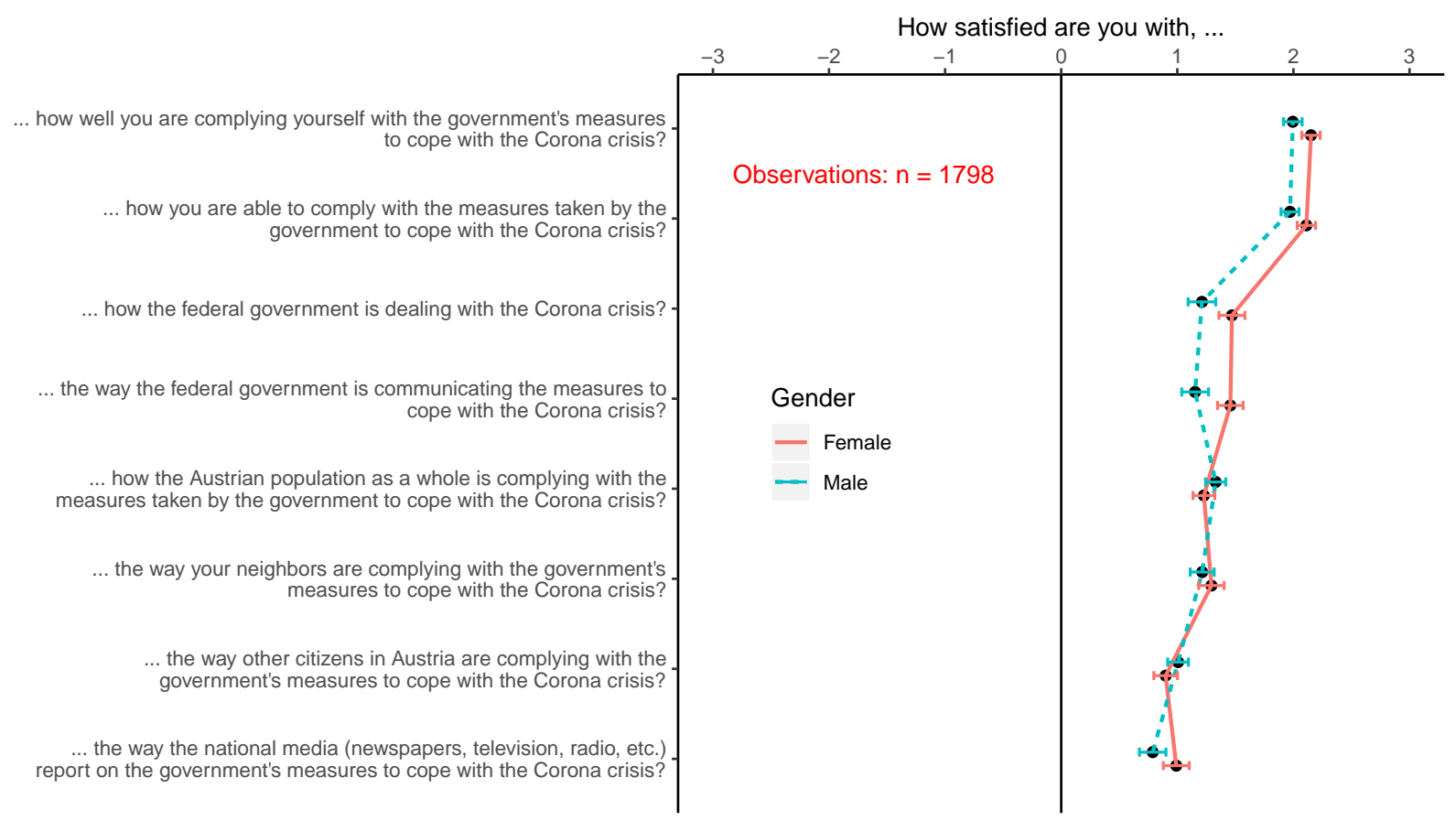

Differences between women and men are non-existing or are very minimal; women are slightly more satisfied with respect to how they comply themselves with the COVID-19 measures, and with how the government is dealing with and communicating about the crisis measures.

Download figure: https://doi.org/10.6084/m9.figshare.12218039 


\subsection{Region}

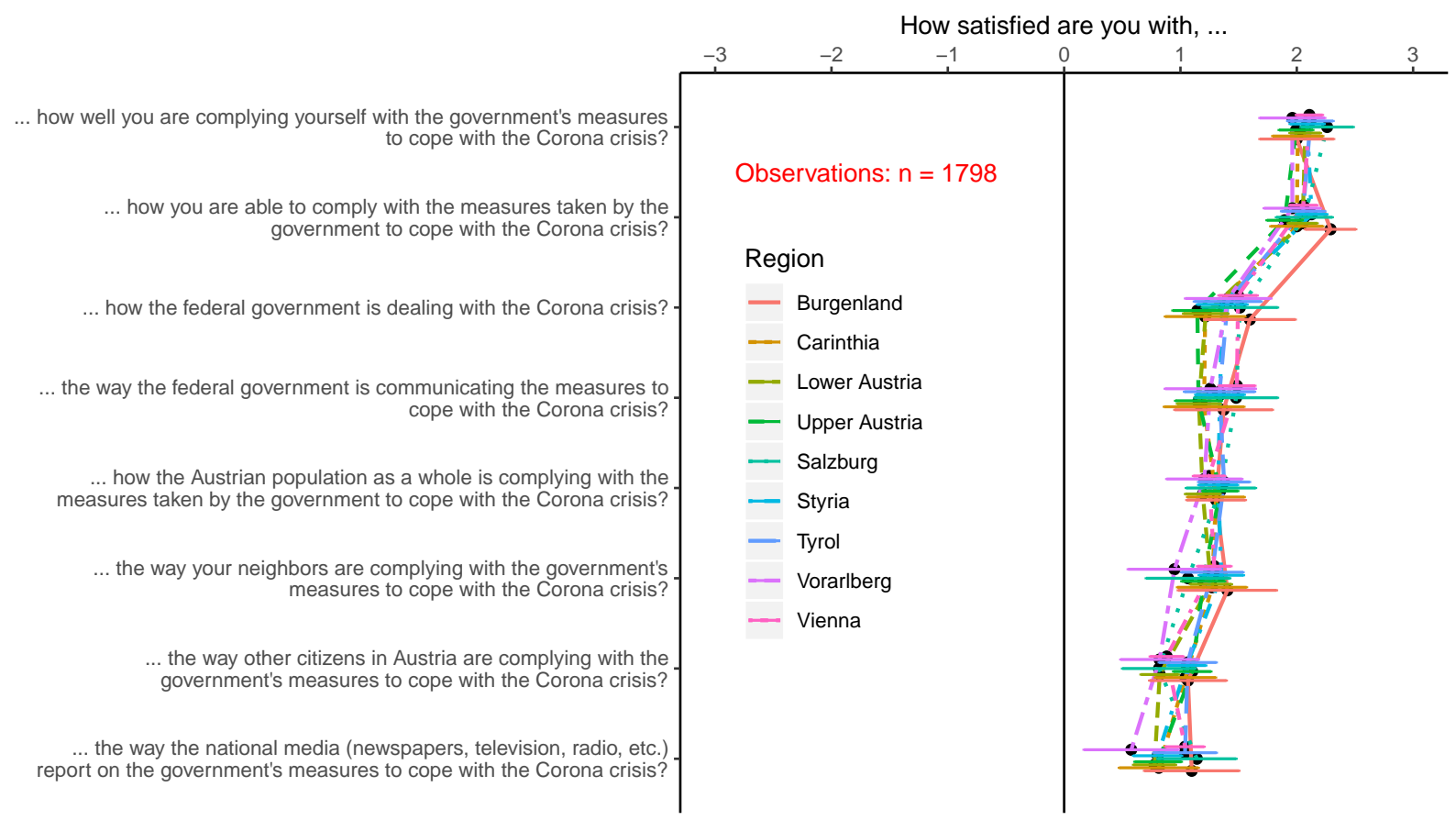

No noteworthy differences for regions, mainly due to relatively wide confidence intervals.

Download figure: https://doi.org/10.6084/m9.figshare.12218051 


\subsection{Occupation}

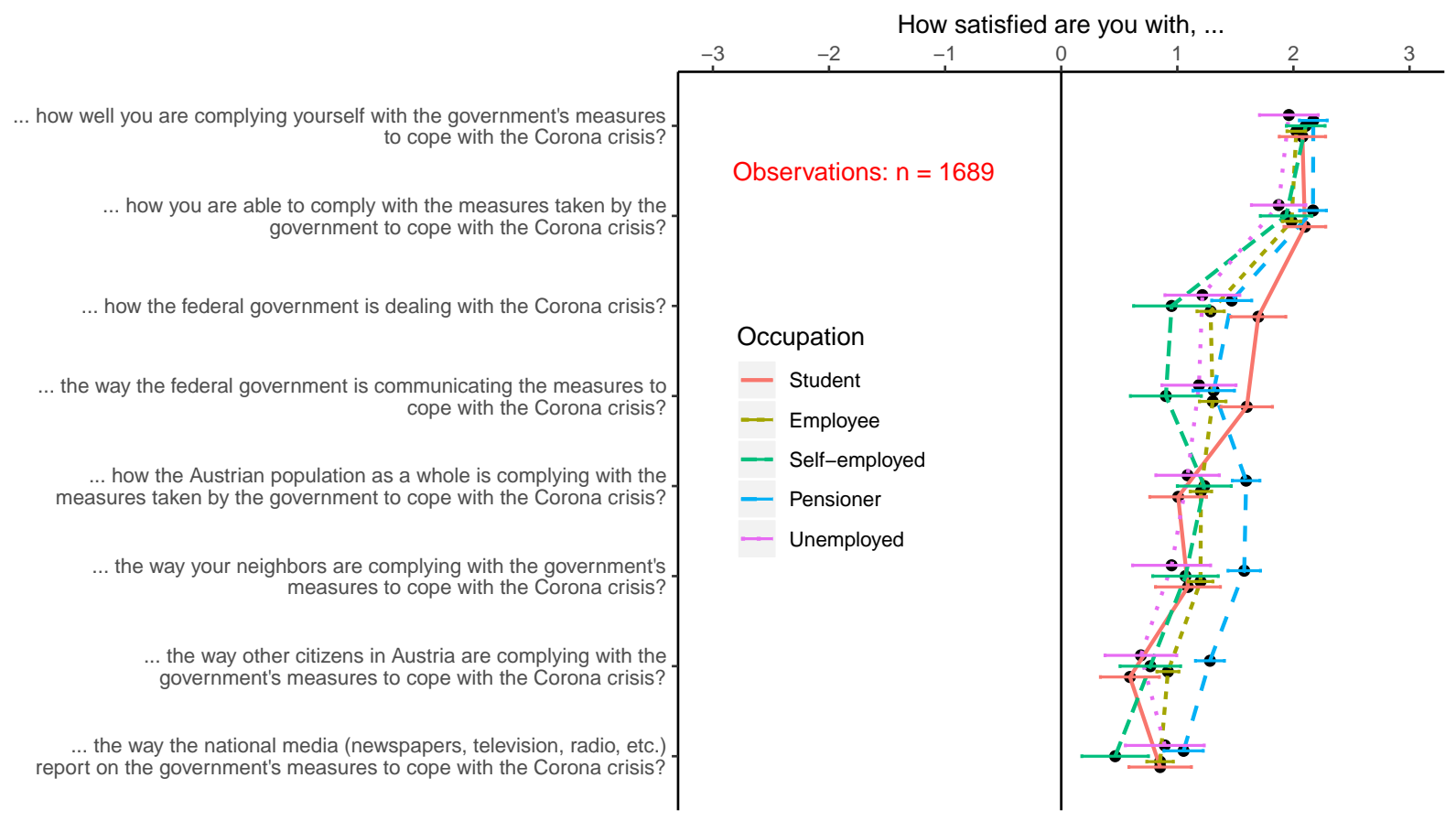

In line with the findings for age, pensioners are more satisfied about how others deal with the COVID-19 measures. Self-employed respondents are least satisfied with how the government is dealing with the crisis and communicating the measures. Students are most satisfied about that. However, it has to be noted that this data is from 17 April to 29 April (2020), which is just before loosening, in a second round, many of the restrictions on small businesses. Respondents that did not classify themselves in one of the categories of this graph, are not reported.

Download figure: https://doi.org/10.6084/m9.figshare.12218057 


\subsection{Education}

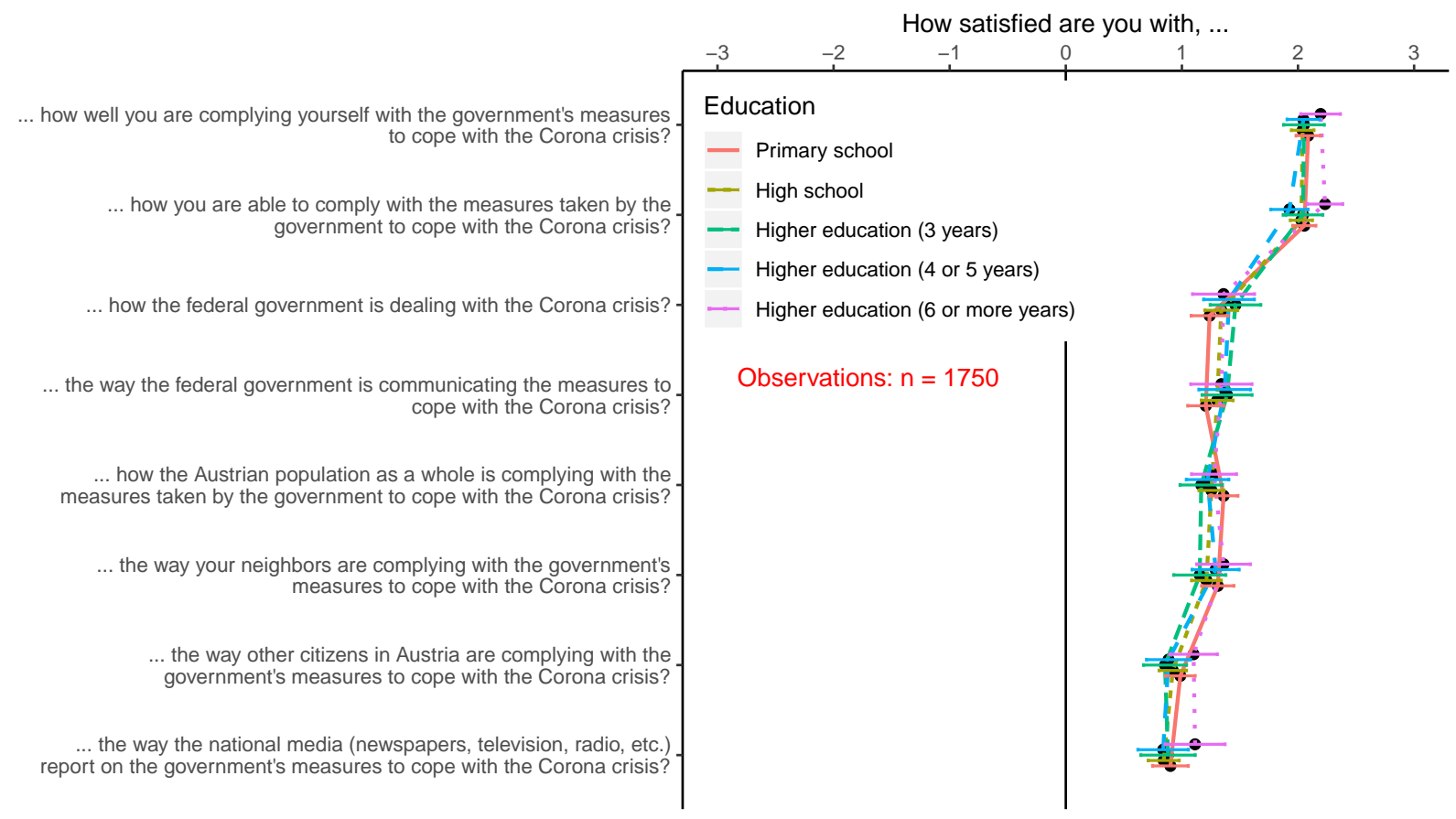

No noteworthy differences for level of education on satisfaction. Respondents that did not classify themselves in one of the categories of this graph, are not reported.

Download figure: https://doi.org/10.6084/m9.figshare.12218066 


\section{Employees $(\mathrm{n}=876)$}

\subsection{General}

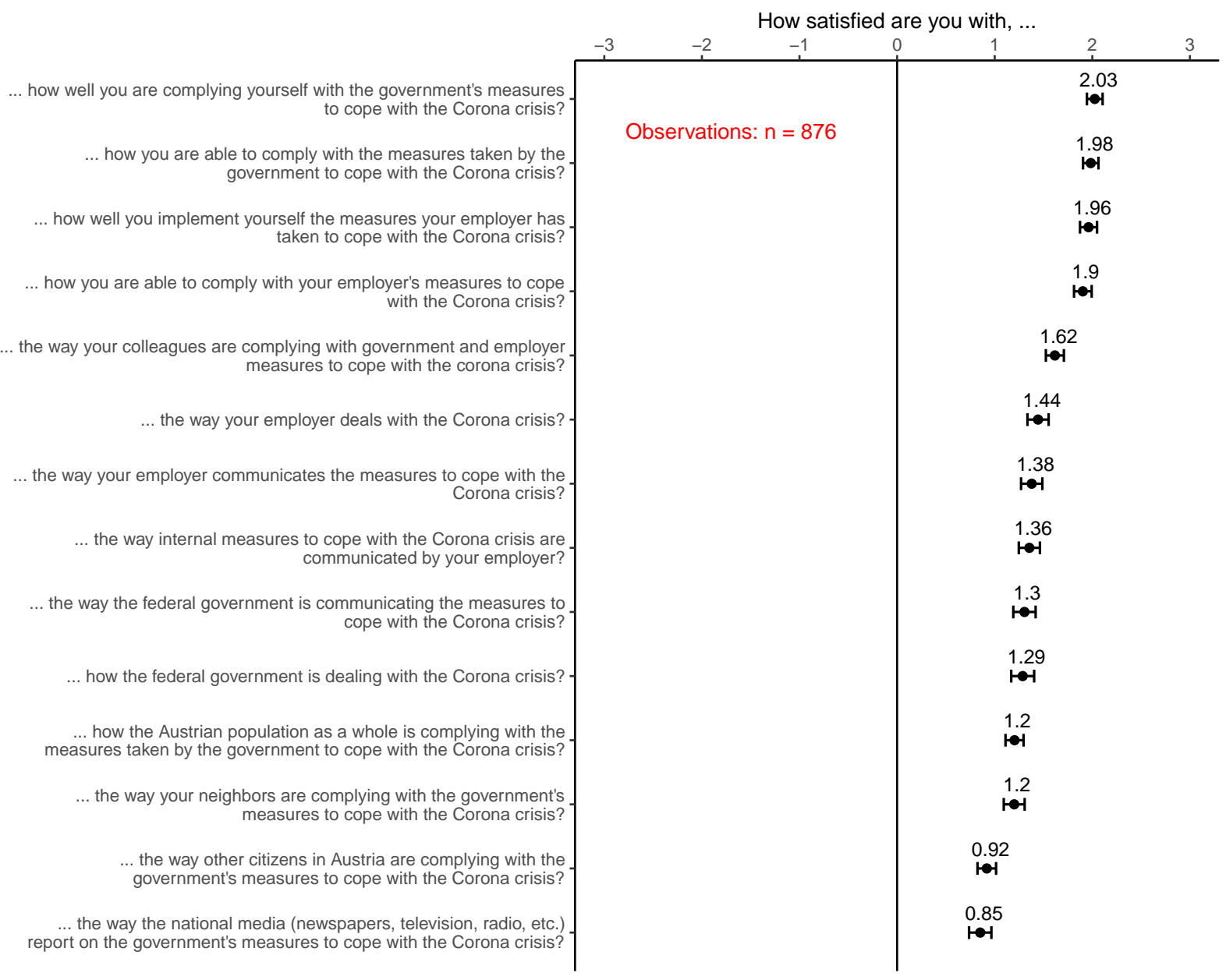

For the subsample of employees $(\mathrm{n}=876)$, all items are again ranked from most satisfied to least satisfied. This time, satisfaction items about employers and colleagues are included; they appear between the previous extreme options and confirm the earlier difference between satisfaction about one self and about others.

Download figure: https://doi.org/10.6084/m9.figshare.12218072 


\subsection{Sector}

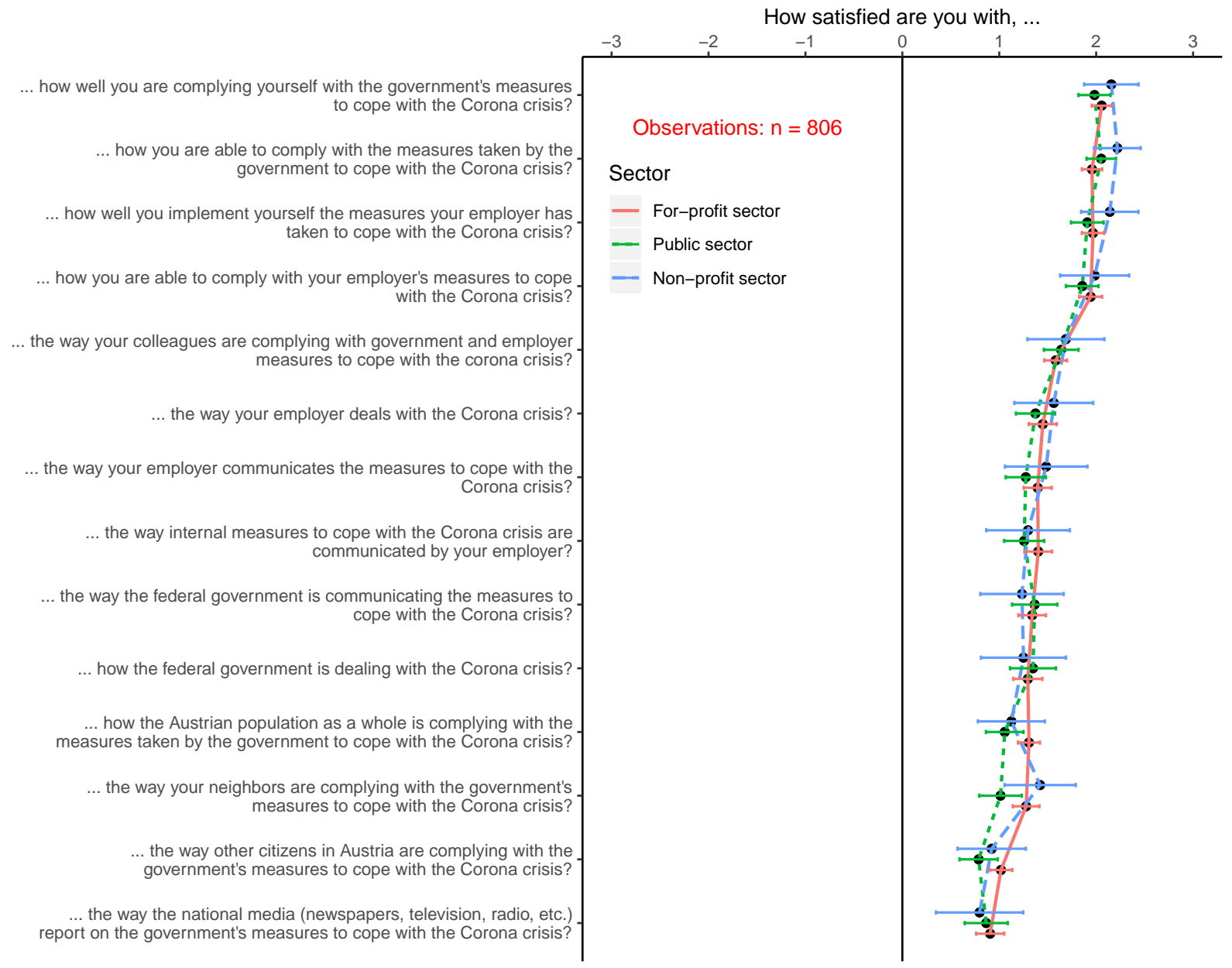

For the subsample of employees that indicate a specific sector of employment $(\mathrm{n}=806)$, we see no substantial differences for sector of employment with respect to satisfaction.

Download figure: https://doi.org/10.6084/m9.figshare.12218081 


\subsection{General (2)}

... how well you implement yourself the measures your employer has
taken to cope with the Corona crisis?

For the subsample of employees $(\mathrm{n}=876)$, this is the selection of items that focus on the work environment (self, employer, and colleagues).

Download figure: https://doi.org/10.6084/m9.figshare.12218096 


\section{Extras}

\subsection{Satisfaction Items}

\begin{tabular}{|c|c|}
\hline Variables & Items \\
\hline OverallSatisfaction_01 & ... how the federal government is dealing with the Corona crisis? \\
\hline OverallSatisfaction_02 & $\begin{array}{l}\text {... the way the federal government is communicating the measures to } \\
\text { cope with the Corona crisis? }\end{array}$ \\
\hline OverallSatisfaction_03 & $\begin{array}{l}\text {... the way the national media (newspapers, television, radio, etc.) } \\
\text { report on the government's measures to cope with the Corona crisis? }\end{array}$ \\
\hline OverallSatisfaction_04 & $\begin{array}{l}\text {... the way your neighbors are complying with the government's } \\
\text { measures to cope with the Corona crisis? }\end{array}$ \\
\hline OverallSatisfaction_05 & $\begin{array}{l}\text {... the way other citizens in Austria are complying with the } \\
\text { government's measures to cope with the Corona crisis? }\end{array}$ \\
\hline OverallSatisfaction_06 & $\begin{array}{l}\ldots \text { how the Austrian population as a whole is complying with the } \\
\text { measures taken by the government to cope with the Corona crisis? }\end{array}$ \\
\hline OverallSatisfaction_07 & $\begin{array}{l}\ldots \text { how you are able to comply with the measures taken by the } \\
\text { government to cope with the Corona crisis? }\end{array}$ \\
\hline OverallSatisfaction_08 & $\begin{array}{l}\ldots \text { how well you are complying yourself with the government's } \\
\text { measures to cope with the Corona crisis? }\end{array}$ \\
\hline OverallSatisfaction_09 & ... the way your employer deals with the Corona crisis? \\
\hline OverallSatisfaction_10 & $\begin{array}{l}\ldots \text { the way your employer communicates the measures to cope with } \\
\text { the Corona crisis? }\end{array}$ \\
\hline OverallSatisfaction_11 & $\begin{array}{l}\text {... the way internal measures to cope with the Corona crisis are } \\
\text { communicated by your employer? }\end{array}$ \\
\hline OverallSatisfaction_12 & $\begin{array}{l}\ldots \text { the way your colleagues are complying with government and } \\
\text { employer measures to cope with the corona crisis? }\end{array}$ \\
\hline OverallSatisfaction_13 & $\begin{array}{l}\text {... how you are able to comply with your employer's measures to cope } \\
\text { with the Corona crisis? }\end{array}$ \\
\hline OverallSatisfaction_14 & $\begin{array}{l}\text {... how well you implement yourself the measures your employer has } \\
\text { taken to cope with the Corona crisis? }\end{array}$ \\
\hline
\end{tabular}




\begin{tabular}{|c|c|}
\hline Variables & Items \\
\hline OverallSatisfaction_01 & ... wie die Bundesregierung mit der Corona- Krise umgeht? \\
\hline OverallSatisfaction_02 & $\begin{array}{l}\text {... wie die Bundesregierung die Maßnahmen zur Bewältigung der } \\
\text { Corona- Krise kommuniziert? }\end{array}$ \\
\hline OverallSatisfaction_03 & $\begin{array}{l}\text {... wie die nationalen Medien (Zeitungen, Fernsehen, Radio usw.) } \\
\text { über die Maßnahmen der Regierung zur Bewältigung der Corona- } \\
\text { Krise berichten? }\end{array}$ \\
\hline OverallSatisfaction_04 & $\begin{array}{l}\text {... wie Ihre Nachbarn die Maßnahmen der Regierung zur Bewältigung } \\
\text { der Corona- Krise befolgen? }\end{array}$ \\
\hline OverallSatisfaction_05 & $\begin{array}{l}\text {... wie andere Bürger*innen in Österreich die Maßnahmen der } \\
\text { Regierung zur Bewältigung der Corona- Krise befolgen? }\end{array}$ \\
\hline OverallSatisfaction_06 & $\begin{array}{l}\text {... wie die österreichische Bevölkerung insgesamt die Maßnahmen der } \\
\text { Regierung zur Bewältigung der Corona- Krise befolgt? }\end{array}$ \\
\hline OverallSatisfaction_07 & $\ldots$ wie Sie selbst in der Lage sind, die Maßnahmen der \\
\hline OverallSatisfaction_08 & $\begin{array}{l}\text { Bundesregierung zur Bewältigung der Corona- Krise zu befolgen? } \\
\text {... wie Sie selbst die Maßnahmen der Regierung zur Bewältigung der } \\
\text { Corona- Krise umsetzen? }\end{array}$ \\
\hline OverallSatisfaction_09 & $\begin{array}{l}\text {... wie Ihr Arbeitgeber / Ihre Arbeitgeberin mit der Corona- Krise } \\
\text { umgeht? }\end{array}$ \\
\hline OverallSatisfaction_10 & $\begin{array}{l}\ldots \text { wie Ihr Arbeitgeber / Ihre Arbeitgeberin die Maßnahmen zur } \\
\text { Bewältigung der Corona- Krise kommuniziert? }\end{array}$ \\
\hline OverallSatisfaction_11 & $\begin{array}{l}\text {... wie interne Maßnahmen zur Bewältigung der Corona- Krise von } \\
\text { Ihrem Arbeitgeber / Ihrer Arbeitgeberin kommuniziert werden. }\end{array}$ \\
\hline OverallSatisfaction_12 & $\begin{array}{l}\text {... wie Ihre Arbeitskolleg*innen die Maßnahmen von Regierung und } \\
\text { Arbeitgeber*in zur Bewältigung der Corona- Krise befolgen? }\end{array}$ \\
\hline OverallSatisfaction_13 & $\begin{array}{l}\ldots \text { wie Sie selbst in der Lage sind, die Maßnahmen Ihres Arbeitgebers } \\
\text { / Ihrer Arbeitgeberin zur Bewältigung der Corona- Krise zu befolgen? }\end{array}$ \\
\hline OverallSatisfaction_14 & $\begin{array}{l}\text {... wie gut Sie selbst die Maßnahmen Ihres Arbeitgebers / Ihrer } \\
\text { Arbeitgeberin zur Bewältigung der Corona- Krise umsetzen? }\end{array}$ \\
\hline
\end{tabular}




\subsection{Correlation of satisfaction items (Employee subset; $\mathrm{n}=876$ )}

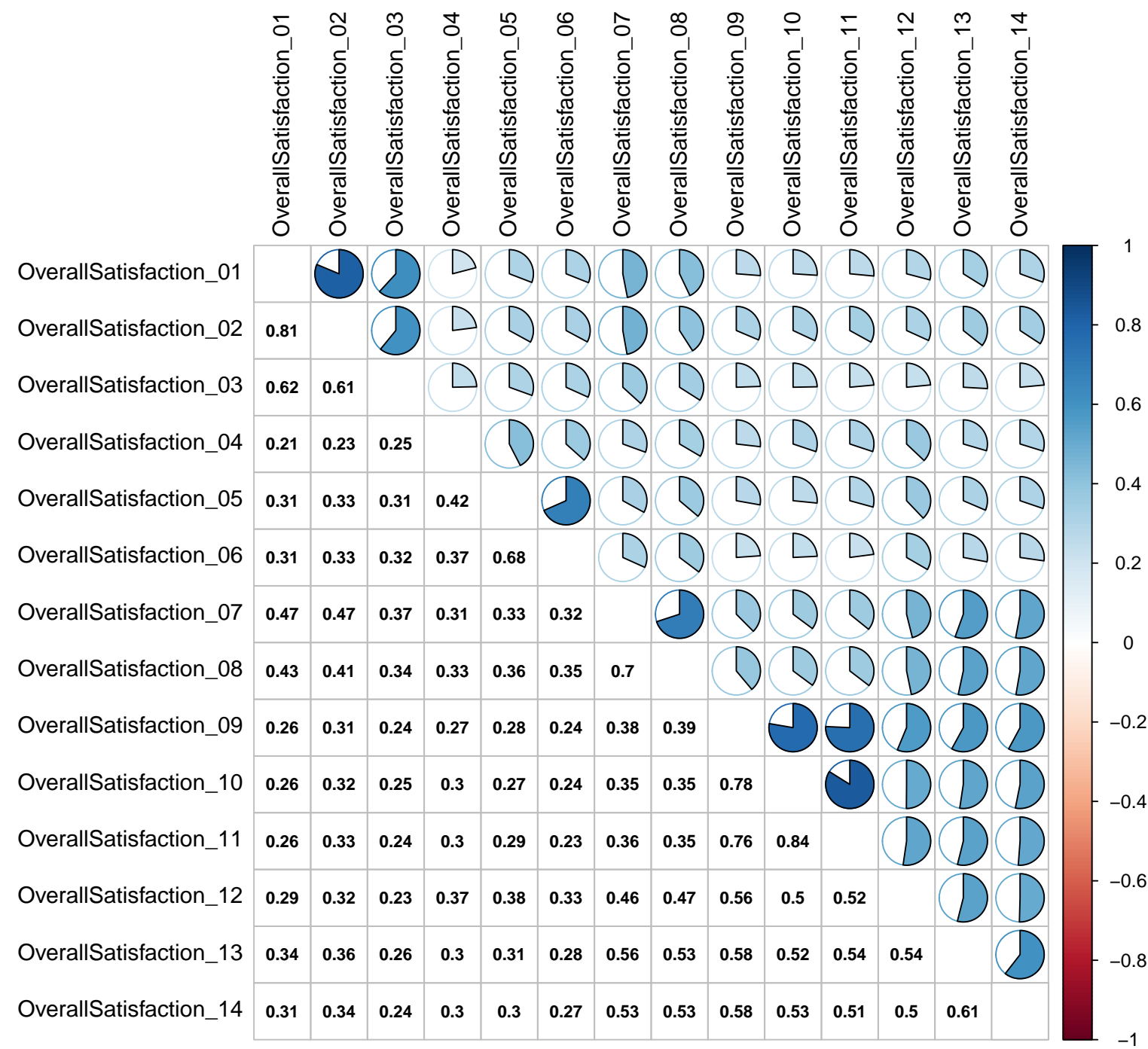




\subsection{Descriptives}

\begin{tabular}{|c|c|}
\hline & DATA $(\mathrm{N}=1,798)$ \\
\hline \multicolumn{2}{|l|}{ Age } \\
\hline Under 30 & $407(22.64 \%)$ \\
\hline Between 30 and 45 & $440(24.47 \%)$ \\
\hline Between 45 and 60 & $563(31.31 \%)$ \\
\hline Above 60 & $388(21.58 \%)$ \\
\hline \multicolumn{2}{|l|}{ Gender } \\
\hline Female & $878(48.83 \%)$ \\
\hline Male & $920(51.17 \%)$ \\
\hline \multicolumn{2}{|l|}{ Region } \\
\hline Burgenland & $62(3.45 \%)$ \\
\hline Carinthia & $118(6.56 \%)$ \\
\hline Lower Austria & $359(19.97 \%)$ \\
\hline Upper Austria & $296(16.46 \%)$ \\
\hline Salzburg & $92(5.12 \%)$ \\
\hline Styria & $259(14.40 \%)$ \\
\hline Tyrol & $128(7.12 \%)$ \\
\hline Vorarlberg & $78(4.34 \%)$ \\
\hline Vienna & $406(22.58 \%)$ \\
\hline \multicolumn{2}{|l|}{ Education } \\
\hline Primary school & $515(28.64 \%)$ \\
\hline High school & $625(34.76 \%)$ \\
\hline Higher education (3 years) & $234(13.01 \%)$ \\
\hline Higher education ( 4 or 5 years) & $217(12.07 \%)$ \\
\hline Higher education (6 or more years) & $159(8.84 \%)$ \\
\hline Answered 'Not applicable' & $48(2.67 \%)$ \\
\hline \multicolumn{2}{|l|}{ Occupation } \\
\hline Student & $142(7.90 \%)$ \\
\hline Employee & $876(48.72 \%)$ \\
\hline Self-employed & $142(7.90 \%)$ \\
\hline Pensioner & $427(23.75 \%)$ \\
\hline Unemployed & $102(5.67 \%)$ \\
\hline \multicolumn{2}{|l|}{ Sector } \\
\hline Profit sector & $512(58.45 \%)$ \\
\hline Public sector & $230(26.26 \%)$ \\
\hline Non-profit sector & $64(7.31 \%)$ \\
\hline Non-Employees, or Answered 'Not applicable' & 922 \\
\hline
\end{tabular}

Other relevant socio-demographic resources on COVID-19 in Austria:

- WWTF COVID-19 Rapid Response Call

- Other projects at the WU, funded by WWTF COVID-19 Rapid Response Call

- Austrian Corona Panel Data (Universität Wien) 